\title{
メレンゲの熱伝導におよぼす起泡条件の影響
}

\author{
水 珠子, 長尾慶子§ \\ 東京家政大学
}

\section{Thermal Conduction in Egg Albumen Foam (Meringue) during Heating}

\author{
Tamako Mizu and Keiko Nagao ${ }^{\S}$ \\ Faculty of Home Economics, Tokyo Kasei University, Itabashi, Tokyo 173-8602
}

\begin{abstract}
Thermal conduction can be induced near the heating plane along the one-dimensional axis ( $x$-axis) in freshly prepared albumen foam of egg (meringue) during heating in a metal vessel at $105^{\circ} \mathrm{C}$. Egg albumen was whipped at about $800 \mathrm{rpm}$ using a kitchen mixer for 90, 180, 240 and $300 \mathrm{~s}$ at room temperature. In the freshly prepared samples, the air bubbles increased in number, but decreased in size as whipping time increased. As all samples were prone to instability over time, all measurements were completed within 50 min after preparation. Steady flow properties and creep behavior were measured to characterize each albumen foam preparation based on plasticity. Both plastic viscosity and Casson's yield value increased with increasing whipping time. Thermal conductivity $\lambda$ and density $\rho$ decreased, while the heat capacity at constant pressure $C_{p}$ increased, with increasing whipping time, giving thermal diffusivity, $\alpha=\lambda / C_{p} \cdot \rho$. Thus, thermal diffusivity of each sample decreased with increasing whipping time. The relationship between the increase in temperature and heating time for all albumen foam samples conformed to an exponential equation based on the assumption that retardation plays a significant role in thermal conduction of albumen foam. This retardation is characterized by the retardation time $\tau(x)$.
\end{abstract}

(Received Apr. 13, 2009 ; Accepted Oct. 15, 2009)

Keywords : albumen foam of egg (meringue), whipping time, thermal conduction, thermal diffusivity, retardation time キーワード : 卵白泡沫系 (メレンゲ)，泡立て時間，熱伝導率，熱拡散，遅延時間

異質の成分が巨視的なかたちで混合された状態が分散系 と総称されることはよく知られているが1), 多岐にわたる調 理操作の過程で対象とする食材に現れる分散系の状態屯多 様である. たとえば，汎用される鶏卵は機械的に攪拌され ることにより空気を細粒状に分散させた泡沫状態を生じさ せ，これが各種のスポンジケーキ素材やメレンゲを調製す る際に用いられることは周知の通りである. 特に鶏卵白泡 沫系については, その状態の持続安定性に及ぼす起泡操作 時間, ショ糖添加量あるいは $\mathrm{pH}$ の影響等が, 試料泡沫系や それに小麦粉を混合したケーキバッターのレオロジー的性 質の時間変化を追跡する方法を通して追究されている ${ }^{2)}$. . 著者の一人は加熱操作において観測される食材内部の温度 上昇速度を非定常熱移動の遅延現象ととらえ, その指標と なる遅延時間の概念を, 各種食材を対象にした加熱実験を 通して提唱してきた5) 12) .さらに，この遅延現象の概念の 適用範囲を検討するため, 液/液分散系であるエマルション 状態の食材や, 気/液分散系である泡沫バッター系を対象 にした実験的検討を進めてきた ${ }^{13)}$ 16). 今回は上記鶏卵白

干173-8602 東京都板橋区加賀 1-18-1

§連絡先 (Corresponding author), nagao@tokyo-kasei.ac.jp
にショ糖を添加して調製した泡沫試料すなわちメレンゲ内 部の熱移動の測定を行なった結果について報告する。

\section{実 験 方 法}

\section{1. 試 料}

卵白泡沫調製用の鶏卵は，すべて市販の新鮮卵を冷蔵庫 に保管し 1 週間以内に使用した。卵白部分の $\mathrm{pH}$ は, 割卵 直後の計測で 8.2〜 8.5 の範囲にあった.

卵白に添加するショ糖は，市販のグラニュー糖（商品名 パールエース E) をそのまま用いた。

\section{2. 鶏卵白泡沫試料の調製}

室温に戻した鵎卵を割卵, 卵白部分を分別採取し，35メッ

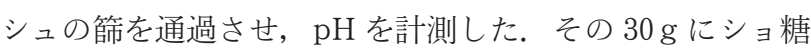
$15 \mathrm{~g}$ (卵白の $50 \mathrm{wt} \%$ ) を加えてガラスボウルに移し, 家庭 用ハンドミキサー (パナソニック製, MK-H3) を用い, ロー ターの回転数約 $800 \mathrm{rpm}$ で室温にて起泡操作を行って鶏 卵白の泡沫試料を得た。泡沫状態に変化を与えるため, 起 泡操作時間を $90 \mathrm{~s}, 180 \mathrm{~s}, 240 \mathrm{~s}$, および $300 \mathrm{~s}$ の四種類に分 け，それぞれを各種測定の対象とし，得られた結果を相互 に比較することとした. 泡粒子の大きさや泡沫体積等の泡 
沫状態は，視覚的には起泡操作時間が増すとともに微細な 泡沫の数が増して良好な系に变化するが， $300 \mathrm{~s}$ 以上の操 作時間では泡沫状態に変化はほとんど見られなくなる．藤 岡ら 2 4) の先行研究によれば, 各種測定に使用し得る鶏卵 白の泡沫試料は, pH 7.2〜8.8においてショ糖添加量 $33 \mathrm{wt}$ $\%$ ，起泡操作時間 $300 \mathrm{~s} \sim 600 \mathrm{~s}$ の系であり，調製直後から 50 min までの時間内で後述の測定に使用し得る状態にあ ると述べている. 本研究においても, 調製後 50 min 以内の 泡沫系を新鮮試料として一連の測定の対象とした。

なお本実験において卵白に砂糖を加えた泡沫試料を以降 メレンゲと略記する.

3. メレンゲ試料のみかけ密度と気泡の体積分率の測定 調製直後の各試料について, 密度測定を実施した。 小型 シャーレ（直径 $32 \mathrm{~mm}$, 高さ $22.5 \mathrm{~mm}$ ）にすり切りに充填 した泡立て直後のメレンゲ各試料の重量を測定し，同様に して測定した水 $\left(25^{\circ} \mathrm{C}\right)$ 重量との比に $25^{\circ} \mathrm{C}$ の水の密度 (997.04 $\left.\left[\mathrm{kg} \cdot \mathrm{m}^{-3}\right]\right)$ を乗じてみかけ密度を算出した。泡立 て時間の異なるメレンゲ試料の気泡体積分率は, 泡立て前 の卵白密度と上記メレンゲ各試料のみかけ密度との比から 算出した (Table 1).

\section{4. 定常流粘度と静的粘弾性（クリープ）の測定}

調製直後の各メレンゲ試料の定常流粘度 $\eta_{\mathrm{N}}$, および一定 応力下でのクリープ挙動をそれぞれ室温 $\left(25^{\circ} \mathrm{C}\right)$ で測定す ることを試みた

定常流粘度測定については円錐平板型回転粘度計（東機 産業製，TVE20-L および TVE20-H）を用い，ローター回 転数を順次低下させる前報の下降プログラム ${ }^{13)}$ 16) を用い て各試料の流動曲線を観測し，見かけの定常流粘度および Cassonの降伏值 ${ }^{17)}$ を求めた。使用したローター半径 24 $\mathrm{mm}$, コーン角 $1^{\circ} 34^{\prime}$ である。

クリープ挙動の測定にはレオメータ（山電製，RE2-330055） を用い, 円筒容器（深さ $65 \mathrm{~mm}$, 直径 $65 \mathrm{~mm}$ ) に充填され

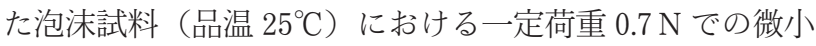
变形量の時間増加を， $300 \mathrm{~s}$ にわたって観測した。得られた クリープ曲線から瞬間弾性率 $\mathrm{E}_{0}$ と粘度 $\eta_{\mathrm{N}}$ を計算した。 測 定に際し, 試料圧縮用プランジャーの半径 $20 \mathrm{~mm}$, 圧縮ひ ずみ率 $5 \%$ 以内とした。

\section{5. 各種熱物性值の測定}

(1) 熱伝導率 $\lambda\left[\mathrm{W} \cdot \mathrm{m}^{-1} \cdot \mathrm{K}^{-1}\right]$

熱伝導率既知の基準物質と試料との平行熱流を比較する 相対的測定法を原理として設計・製作した既存の熱伝導率

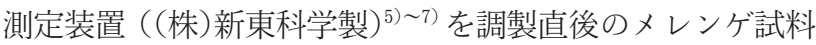
にも適用した。低温側温度を $20,40,60$ および $80^{\circ} \mathrm{C}$, 高温 側の温度をそれぞれ $+5^{\circ} \mathrm{C}$ に設定 $\left(25,45,65\right.$ および $\left.85^{\circ} \mathrm{C}\right)$ して熱伝導率を測定した。本測定装置および測定実施の詳 細については，既報5)で述べた通りである。

（2）定圧比熱容量 $C_{p}\left[\mathrm{~J} \cdot \mathrm{kg}^{-1} \cdot \mathrm{K}^{-1}\right]$

本測定も， 既報 ${ }^{5)}$ で述べた自作の水熱量計を調製直後の
Table 1 The measured apparent density and volume fraction of air of meringues arranged under various whipping times at $25^{\circ} \mathrm{C}$

\begin{tabular}{rcc}
\hline $\begin{array}{c}\text { Whipping time } \\
{[\mathrm{s}]}\end{array}$ & $\begin{array}{c}\text { Apparent density } \\
{\left[\mathrm{kg} \cdot \mathrm{m}^{-3}\right]}\end{array}$ & $\begin{array}{c}\text { Volume fraction } \\
\text { of air }\end{array}$ \\
\hline 0 & $1080 \pm 1.0$ & 0.00 \\
90 & $349 \pm 20.6$ & 0.68 \\
180 & $267 \pm 15.0$ & 0.75 \\
240 & $246 \pm 4.2$ & 0.77 \\
300 & $207 \pm 5.0$ & 0.81 \\
\hline$n=5$ & &
\end{tabular}

メレンゲ試料に適用し, 定圧比熱容量 $C_{p}$ を求めた。 但し, 使用した装置は力学的強度の高い小麦粉ドウ等に用いたも のを転用したため，保形性の低い泡沫系への適用に対し， 予備実験を行い実験操作の習熟に努めた。

(3) 熱拡散率 $\alpha\left[\mathrm{m}^{2} \cdot \mathrm{s}^{-1}\right]$ の算出 ${ }^{5) \sim 7718)}$

熱拡散率（温度伝導率） $\alpha$ は，熱エネルギーの非定常移 動現象において，運動エネルギーの移動における動粘度や 質量の移動に扮ける拡散係数と同じ次元 $\left[\mathrm{m}^{2} \cdot \mathrm{s}^{-1}\right]^{19)}$ を有 する移動係数である。これは試料内部の温度分布が時間的 に変化する場合に考慮されるべき係数 ${ }^{19)}$ であり，それは伝 熱量の大小ではなく, 温度変化の速度に対応する熱物性值 であって, 試料の熱伝導率 $\lambda$, 定圧比熱容量 $C_{p}$ および密度 $\rho$ の各值から次式により計算される.

$$
\alpha=\lambda / C_{p} \cdot \rho
$$

\section{6. 加熱下でのメレンゲ試料内部における熱移動速度の 測定}

これまでの各種食材を対象にした加熱実験において，加 熱装置モデルとして用いた金属容器内の間接加熱(6) あるい は直接加熱7)のいずれの場合も，加熱面から試料内部一次 元方向（ $x$ 軸方向）各位置における温度の経時変化を記録 し, 得られた各温度上昇曲線が遅延現象として特徵付けら れることを明らかにしている(6)7). 今回のメレンゲ試料の場 合は金属製加熱容器内における間接加熱に相当するが，こ れまでと同様の方法 ${ }^{6)}$ で熱源の温度を $105^{\circ} \mathrm{C}$ 一定とした場 合の，加熱面加 試料内部一次元方向（ $x$ 軸方向） $0 \sim 10$ $\mathrm{mm}$ の範囲における各位置 $(0,1 ， 3 ， 5 ， 7,10 \mathrm{~mm})$ の温 度变化を測定し，熱移動速度の解析を試みた。温度測定に は $x$ 軸方向の各位置にそれぞれ熱電対 (安立計器製 TypeK, 直径 $0.1 \mathrm{~mm}$ ）を設け, 各熱電対からの温度信号をデーター コレクター（安立計器製 AM-7002）に記録し，温度上昇曲 線の解析に供した。

\section{実験結果と考察}

\section{1、新鮮なメレンゲ試料のレオロジー的性質}

（1）定常流動下に求ける粘度挙動

Fig. 1 (A) に起泡操作時間の異なる四種類のメレンゲの 
温度 $25^{\circ} \mathrm{C}$ における流動曲線（ずり速度〜ずり応力の関係） を示す。これら流動曲線の低ずり速度における 38.3-76.6 s $\mathrm{s}^{-1}$ の值を用いて算出した Casson の降伏值の起泡時間による 影響を Fig. 1 (B) にプロットした。これらの結果から，本 実験試料のメレンゲがおよそ $20 \mathrm{~Pa} \sim 60 \mathrm{~Pa}$ の範囲の降伏 值を有する塑性流体であること，降伏值や塑性粘度の值は 起泡操作時間が長くなるほど大きくなることが明らかであ る。いずれも，泡沫を構成する液体膜面積の増加，言い換 えれば泡沫個数の増加に伴い泡沫系内部に取り込まれる空 気量が増大することに基づいて現われた結果であると考え られる。

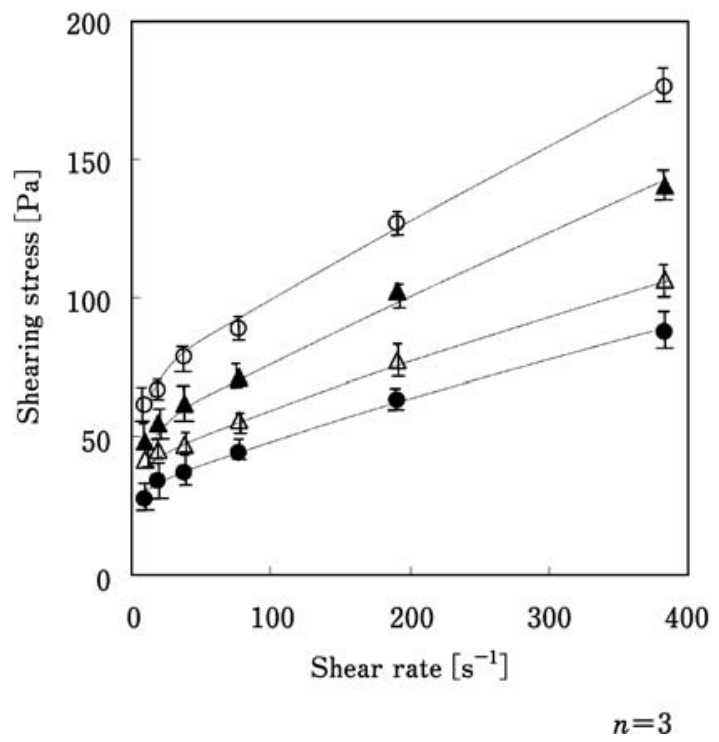

Fig. 1-(A) Correlation between the shear rate and the shearing stress of meringues arranged under various whipping times at $25^{\circ} \mathrm{C}$

Whipping time $[\mathrm{s}]: \bullet, 90 ; \triangle, 180 ; \boldsymbol{\Lambda}, 240 ; \bigcirc, 300$.

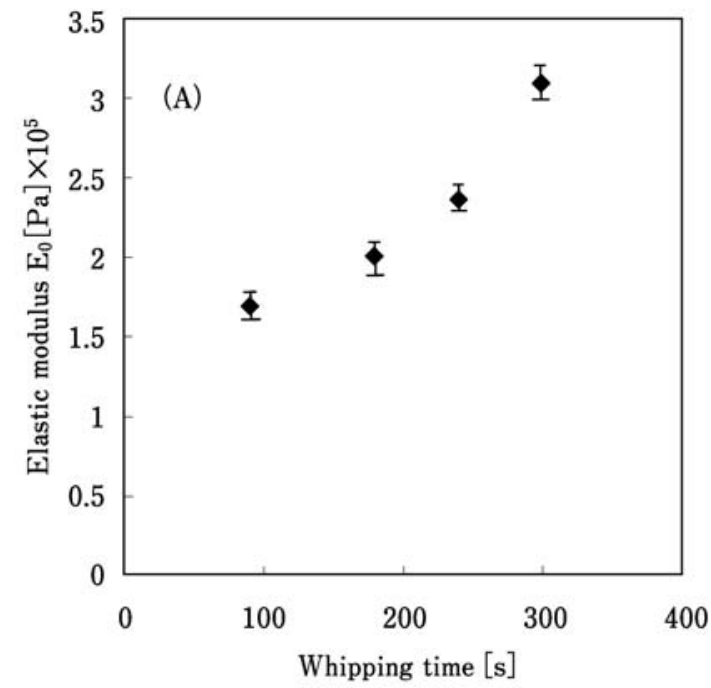

$n=3$
(2) 微小変形下でのレオロジーパラメーター

圧縮ひずみ $5 \%$ 以内に打けるメレンゲ試料のクリープ曲 線から静的弾性率 $\mathrm{E}_{0}$ および静的粘性率 $\eta_{\mathrm{N}}$ をそれぞれ求 めた．この場合も，Fig. 2(A) の静的弾性率および同（B） の静的粘性率と起泡操作時間とのそれぞれの関係に見られ るように，泡沫状態の成長とともに各レオロジーパラメー 夕ーの值は増大する，その理由は，定常流粘度の増加の場 合と同様であると考えられる。

2. メレンゲ試料の熱的諸性質

（1）温度上昇曲線におよぼす起泡操作時間の影響 起泡操作時間が $90 \mathrm{~s} ， 180 \mathrm{~s} ， 240 \mathrm{~s}$ および $300 \mathrm{~s}$ の各試料

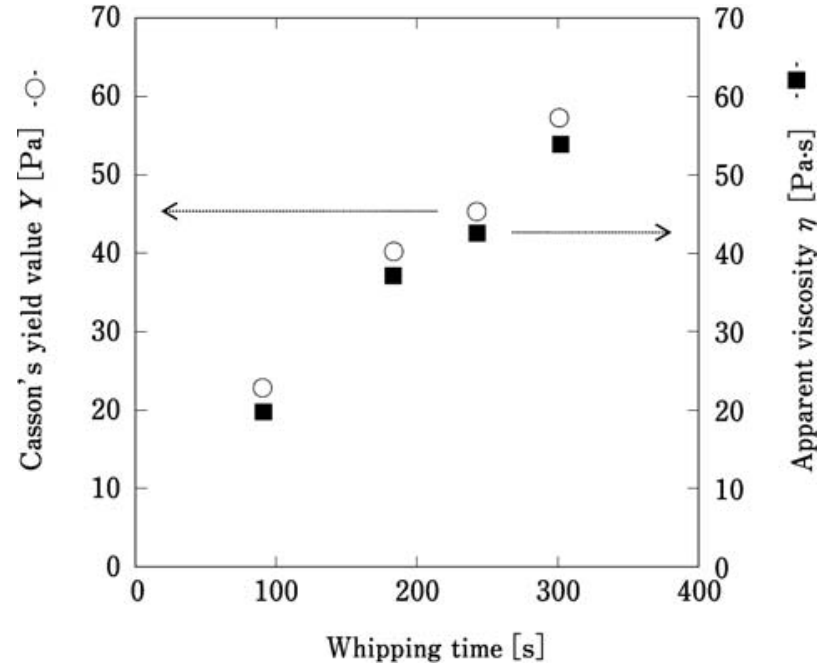

Fig. 1-(B) Effect of whipping time on the Casson's yield value and apparent viscosity at low shear rate ranging from $38.3 \mathrm{~s}^{-1}$ to $76.6 \mathrm{~s}^{-1}$ at $25^{\circ} \mathrm{C}$

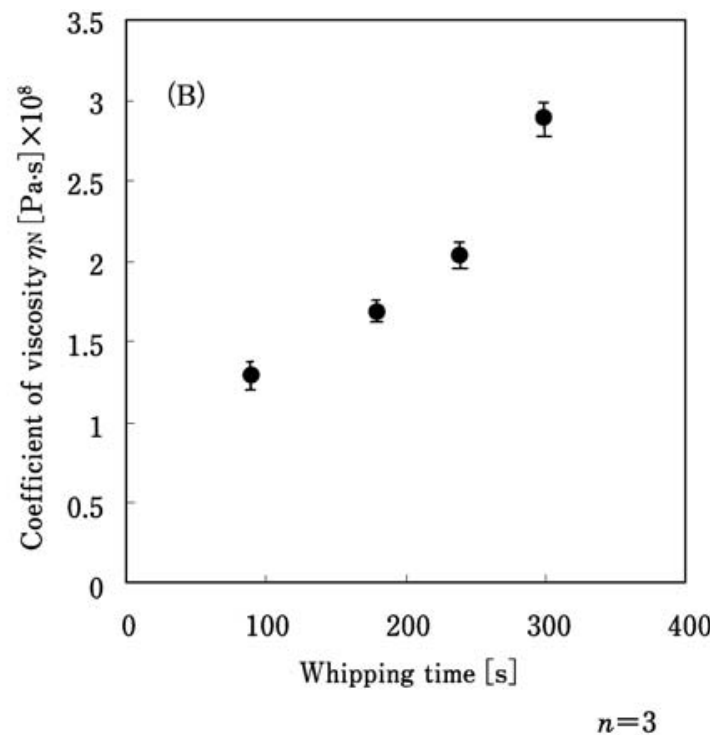

Fig. 2-(A), (B) The measured elastic modulus and coefficient of viscosity of the meringues arranged under various whipping times at $25^{\circ} \mathrm{C}$ 


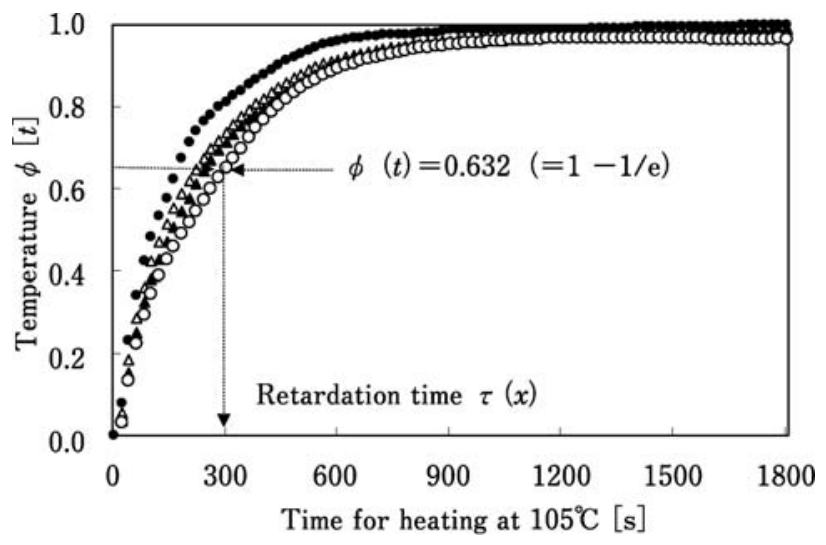

Whipping time $[\mathrm{s}]: \bullet, 90 ; \triangle, 180 ; \boldsymbol{\Lambda}, 240 ; \bigcirc, 300$.

Fig. 3 Comparison of the curves of increasing temperature detected at $3 \mathrm{~mm}$ from heating plane in meringues arranged under various whipping times, showing the method of calculating retardation time $\tau(x)$

の一定加熱下（熱源温度 $105^{\circ} \mathrm{C}$ ) における温度上昇曲線を, 加熱面から試料内部 $x$ 軸方向 $3 \mathrm{~mm}$ の位置について Fig. 3 に例示した. Fig. 3 の温度上昇各曲線は，これまでに計測 の対象にした種々の状態の食材と同様 ${ }^{5)}$ 14), 次の形式に 従って記述したものである.

$$
\phi(t)=1-\exp [-t / \tau(x)]
$$

ただし， $\phi(t)$ は次の (3) 式で表わされる無次元温度として 図の縦軸に示している。すなわち,

$$
\phi(t)=\left(T_{t}-T_{0}\right) /\left(T_{\infty}-T_{0}\right)
$$

ここに， $\phi(t)$ は加熱時間 $t$ におけるメレンゲ試料内部 $x$ の位置の無次元温度であり, 加熱前, 加熱中および加熱終 了時の試料内部温度をそれぞれ $T_{0}, T_{t}, T_{\infty}$ として(3) 式か ら計算することができる. また, $\tau(x)$ は同位置 $x$ の温度上 昇速度を律する時間定数, すなわち遅延時間に相当するも ので5 7), 温度上昇曲線の測定過程で観測される無次元温 度 $\phi(t)$ が加熱終了時の最終温度 $\phi(\infty)$ の $0.63(=1-1 / \mathrm{e})$ に達するのに要する時間である。この結果から明らかなよ うに，伝導伝熱に基づくメレンゲ試料内部温度の上昇速度 は起泡操作時間の長い試料ほど緩慢になる傾向が認められ た.このことから，一定条件で加熱した時のメレンゲ試料 内部の温度上昇速度は, 起泡操作時間が長くなって空気取 り込み量すなわち気泡数が増すほど緩慢になる傾向が見ら れ, 一定加熱条件下での温度上昇速度を律する遅延時間 $\tau(x)$ は長くなる.なお, 本実験におけるメレンゲ試料に対 して起泡操作時間の長短に関わらず上述の (2) 式の関係が 成立することから，Fig. 4 に示すように加熱中の無次元温 度の測定値と計算值との間に高い相関が存在する.

併せて, 上述の実験結果から，きわめて多量の気泡から

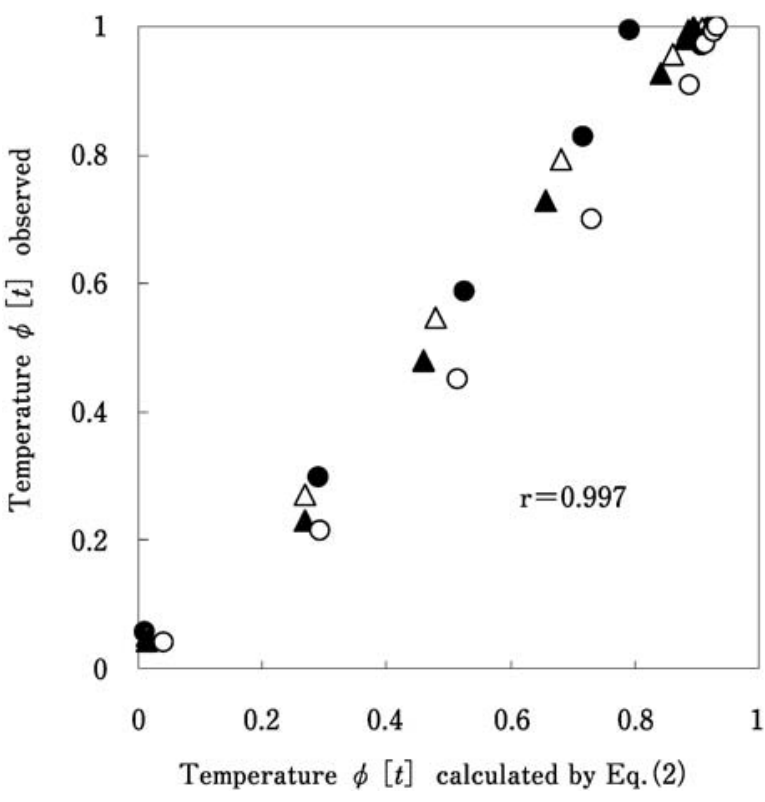

Whipping time [s] :, $90 ; \triangle, 180 ; \mathbf{\Delta}, 240 ; \bigcirc, 300$.

Fig. 4 Correlation between dimensionless temperature measured $\phi[\mathrm{t}]$ and those calculated by Eq. (2) during heating in a metal vessel for the case of the meringues arranged under various whipping times. Location $(x)=3 \mathrm{~mm}$

なるメレンゲ試料が伝導伝熱によって系全体の温度変化を 律する事実は重要である。すなわち, 泡沫系の伝熱機構に おいて, 泡沫生成量が増すほど伝熱速度を支配する液体膜 の薄化が進み, 熱移動量が低下する傾向が Fig. 3 の結果に 現われていると考えられる ${ }^{20)}$. この状況は, Fig. 5 の熱伝導 率の值に示すように, 多量の空気が断熱材的な役割をして高 温側からの熱の移動を妨げている結果であると推測される.

(2) 熱拡散率 $\alpha$ におよぼす起泡操作時間の影響

一定加熱条件下でのメレンゲ試料内部の熱移動速度が泡 沫生成の程度に影響されることが明らかになったが，前述 の通り非定常熱移動速度を律する熱拡散率 $\alpha$ 〔熱伝導率 $\lambda /$ (定圧比熱容量 $C_{p}$ ・密度 $\rho$ ) ] の温度伝導に対する寄与を 検討することは重要である. 起泡操作時間が $90 \mathrm{~s}, 180 \mathrm{~s}$, $240 \mathrm{~s}$ および $300 \mathrm{~s}$ の各メレンゲ試料 $\left(25^{\circ} \mathrm{C}\right)$ の熱拡散率 $\alpha$ の変化を Fig. 6 に示したように，操作時間が長くなり気泡 体積分率が増すほど（Table 1)，熱拡散率の值は低下する 傾向が見られた。Fig. 6 では省略したが，熱拡散率はこれ までと同様に測定温度とともに大きくなるタイプの温度依 存性がみられた。

前述したように，非定常移動現象において誘起される熱 の流れはメレンゲ試料内部の互いに隣接する液体膜の部分 で次々に生じ，このようにして液体膜の一部に生じた温度 上昇は次第に伝播して行くことが推察される。このような 一種の伝播現象 ${ }^{20)}$ を媒介する液体膜の厚さが熱流の速度 に影響する状況が考えられ，本実験ではそれが薄くなるほ 


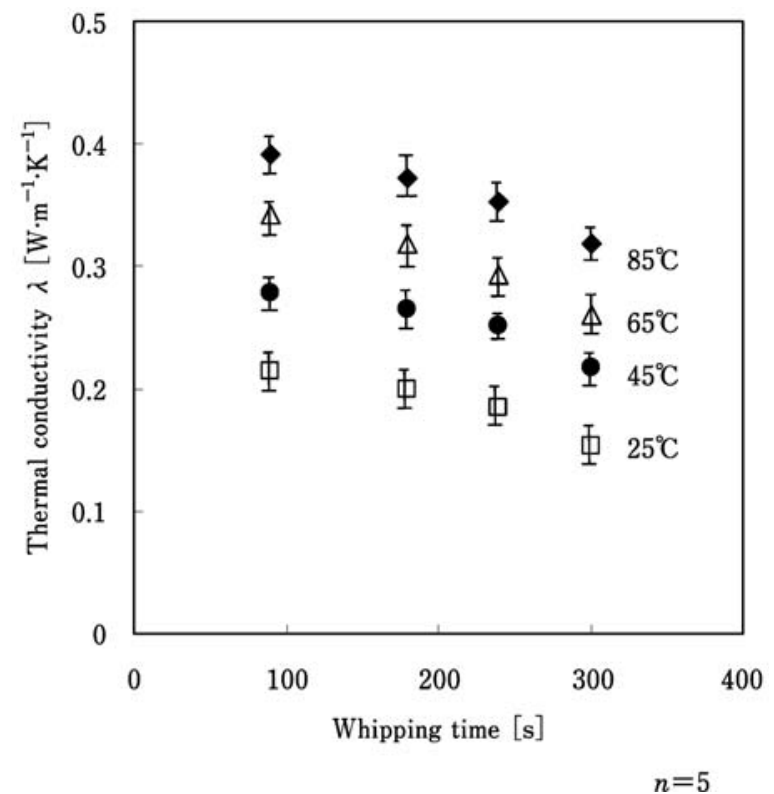

Fig. 5 Thermal conductivity of egg white meringue arranged under various whipping conditions

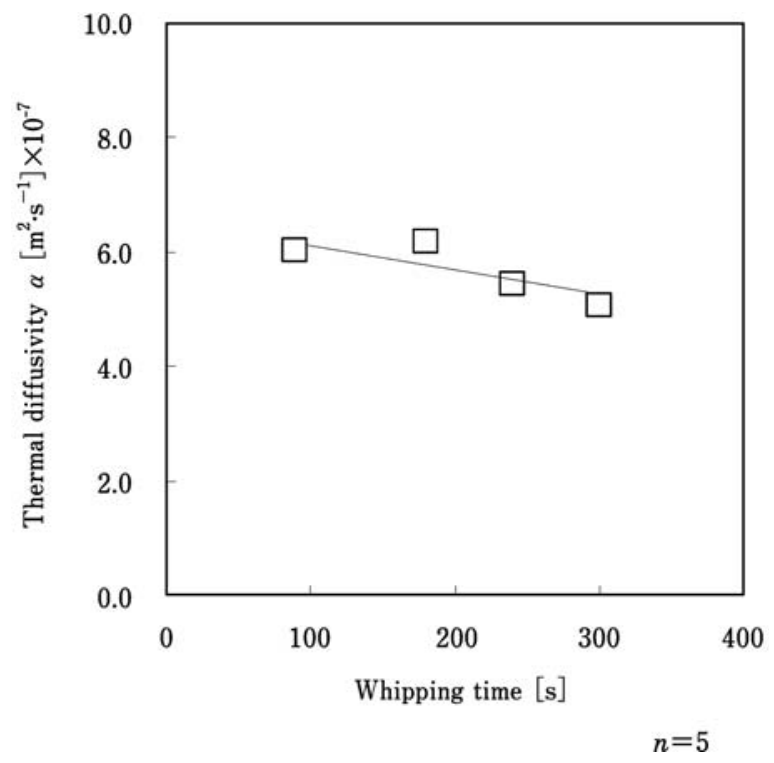

Fig. 6 Effect of whipping time on the thermal diffusivity for meringues at $25^{\circ} \mathrm{C}$

ど熱の流れる速度が緩慢になる傾向にあると言えるであろ う。そして，この熱拡散率と起泡操作時間との関係は，定 圧比熱容量 $C_{p}$ の值（Fig. 7）が同操作時間を長くすれば大 きな值を示す測定結果を反映したものといえる。すなわち 熱伝導率の值 (Fig. 5) でも述べたように, 気泡体積分率の 多い試料ほよ゙，熱伝導の低い空気が断熱材的働きをして高 温側からの熱の移動を緩慢にしていると考えられ， $C_{p}$ の值 から一定温度に到達させるには多量の熱量を要することが 推察される.

（3）メレンゲ加熱時の遅延時間 $\tau(x)$ と熱拡散率 $\alpha$ との 関係

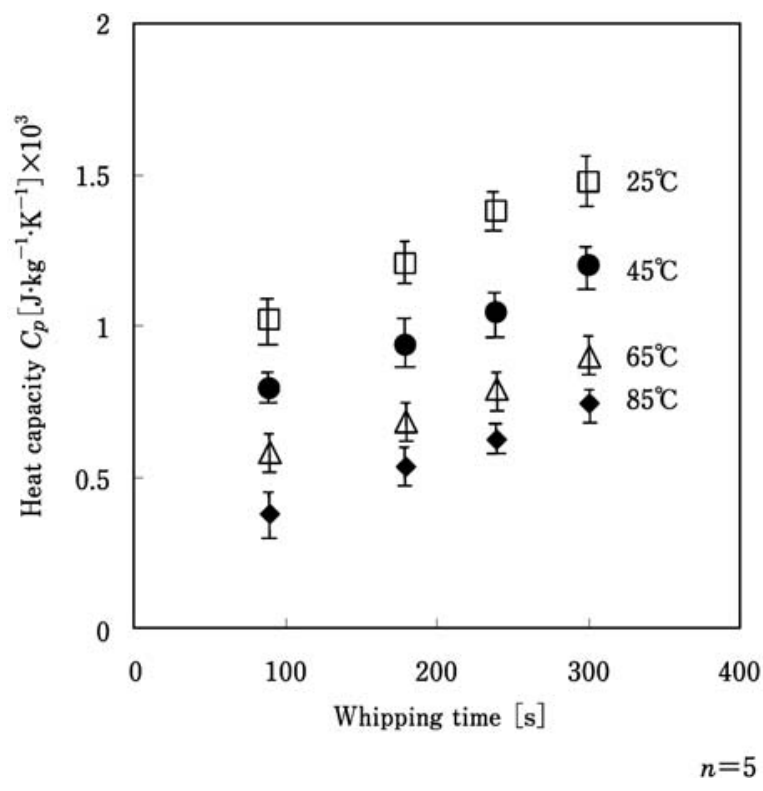

Fig. 7 Heat capacity at constant pressure of meringues arranged under various whipping conditions

種々の状態の食材を対象にしたこれまでの実験研究5) 7) において, 加熱中の試料内部 $x$ の位置における温度上昇速 度を律する遅延時間 $\tau(x)$ と試料の熱拡散率 $\alpha$ との間に, 指 数関数の関係が存在することを指摘してきた。 このことが 本実験におけるメレンゲ試料にも適合するか否かを確かめ るため, 起泡操作時間の異なる各試料の熱拡散率 $\alpha\left[\mathrm{m}^{2} \cdot \mathrm{s}^{-1}\right]$ に対し, 試料内部 $x=3 \mathrm{~mm}$ 位置での各試料の昇温曲線か ら求めた遅延時間 $\tau(x)$ と試料加熱面積 $S\left(=1.25 \times 10^{-3} \mathrm{~m}^{2}\right)$ との比 $S / \tau(x)\left[\mathrm{m}^{2} \cdot \mathrm{s}^{-1}\right]$ を両対数座標上にプロットするこ

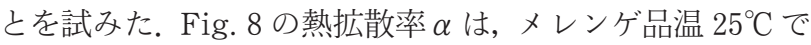
の熱伝導率，比熱容量およびみかけの密度を用いて算出し たもので，両者の関係をみたところ，これまでの実験に用 いた他の食材と同様，泡沫系内の熱移動に関わる熱拡散率 之遅延時間の間に両対数座標上で一定の相関関係が存在す ることが確認された。したがって次の関係が本実験研究に おいても得られたことになる。すなわち,

$$
S / \tau(x)=k \cdot \alpha^{n}
$$

ここに， $k$ は係数， $n$ は熱拡散率 $\alpha$ の係数である.

これまでの実験研究において得られた知見によれば，係 数 $n$ の值は試料の種類を問わず加熱の方法を反映し ${ }^{6) 7}$, 本実験に用いたような間接加熱（pan broiling）の場合, 小麦粉ドウやマッシュポテトなどの可塑性試料などの一般 食材の平均值として加熱面から $3 \mathrm{~mm}$ の位置で 0.652 なる 值を得ている(6)7)18). 本論文においても, Fig. 8 から求めら れるべキ指数式から $n=0.702$ が得られているが，その值 はマヨネーズなどの転相や分散状態が変化しやすい乳化

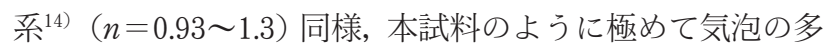
い不安定系試料においては，今後加熱中に生じる種々の現 


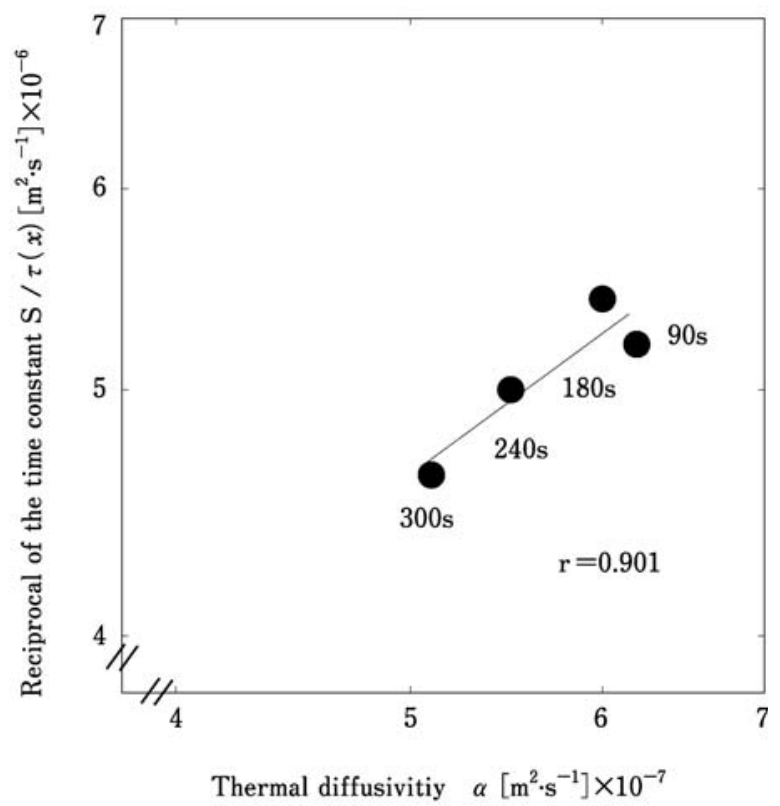

Fig. 8 Double logarithmic plots of the retardation time against the thermal diff usivity $\alpha$ at $25^{\circ} \mathrm{C}$

( $\mathrm{r}$; correlation coefficient). $\mathrm{S}$ is the area of the heating plane $\left(=1.25 \times 10^{-3} \mathrm{~m}^{2}\right)$.

象の影響も考慮し情報の収集に努める必要がある.

要約

（1）メレンゲのような卵白とショ糖との混合物で調製さ れた泡沫系を対象に， $105^{\circ} \mathrm{C} に$ に打る間接加熱下での内部 熱移動にかかわる一連のモデル加熱実験を行った。

（2）家庭用ハンドミキサーを用い，ローターの回転数を $800 \mathrm{rpm}$ 一定として室温でボウル内の上記混合物を $90 \mathrm{~s}$, $180 \mathrm{~s}, 240 \mathrm{~s}$ および $300 \mathrm{~s}$ の起泡操作の結果, 分散空気量 (気泡体積分率) の異なる四種類の泡沫試料を得た。すなお ち, 起泡操作時間が長いほど分散空気量が増し，泡は微細 化されるが，操作時間が $300 \mathrm{~s}$ を越えるとそれらは一定値に ほぼ収束する。いずれも状態変化の早い試料であるので, 以下の測定は全て調製後 $50 \mathrm{~min}$ 以内に実施した.

（3）定常流動下での流動曲線, および微小変形下でのク リープ挙動からそれぞれ求められる降伏值, 定常流粘度, 静的弾性率, 静的粘度はいずれ屯起泡操作時間が長い試料 ほど大きな值を示すことから, 試料中の分散気泡量が増 し, 気泡が小さくなるほど粘稠で硬度のあるメレンゲ試料 が生成することが示唆される。

（4）起泡操作時間の長い試料ほど非定常熱移動を律する 熱拡散率の值が低くなるが, その原因は起泡操作時間が長 くなるほどメレンゲ試料の熱伝導率が低く, 定圧比熱容量 が高くなる傾向が現われるためと考えられた。

（5）金属製容器内での加熱操作（pan-broiling）による
メレンゲ試料内部の温度上昇速度は，加熱面から試料内部 $x$ 軸方向に打いて遅延現象として解析可能な形式に従うこ とが認められた。この形式は，これまでに実施された種々 の状態の食材を対象にした加熱下での熱移動測定の結果に 一致する。

\section{文献}

1）松本幸雄, 食品の物性とは何か, （弘学出版, 東京） p 85, (1991).

2）藤岡利子, 松本幸雄, 鷂卵白泡沫の安定性に対するレオロ ジー的評価の試み, 調理科学, 27, 7-13 (1994).

3）藤岡利子, 松本幸雄, 鶏卵白泡沫バッターの応力緩和, 調理 科学, 28, 91-95 (1995).

4) Fujioka, T. and Matsumoto, S., Factors Affecting the Viscoelastic Properties of Albumen Foams, J. Texture Stud., 26, 411-419 (1995).

5) Nagao, K. and Matsumoto, S., Preparation of Food Models for Examining Heat Transfer in Cooking under the Control of Moisture, J. Cookery Sci. Jpn., 32, 10-17 (1999).

6) Nagao, K. and Matsumoto, S., Thermal Conduction along by the One-Dimensional Axis in Foodstuffs during Heating in a Metal Vessel, J. Home Econ. Jpn., 52, 241-249 (2001).

7) Nagao, K. and Matsumoto, S., Detection of the Thermal Conduction Induced Close by the Heating Plane in Foodstuffs during Different Procedures of Heating, J. Home Econ. Jpn., 54, 623-631 (2003).

8）藤井彩香，長尾慶子，小麦でん粉を用いた食材モデル系の 伝熱特性の検討，日調科誌，37，283-291（2004）.

9）長尾慶子，加熱により相変化をともなう食材系の熱移動之 力学的性質の变化, 家政誌, 55, 837-844 (2004).

10）長尾慶子, 喜多記子, 天野里香, 森田真由美, 香西みよ゙り, 畑江敬子, 包み焼きに用いる各種包材の伝熱特性, 日調科 誌，38，491-496 (2005).

11）喜多記子, 長尾慶子, 加熱用食材モデル系としての純ココ アの役割，家政誌， 56，597-605（2005）.

12）長尾慶子， 喜多記子，加熱下での食材の熱伝導に及ぼす熱 不活性成分の影響，家政誌，57，229-237（2006）.

13）水 珠子, 長尾慶子, 卵黄で調製した $\mathrm{O} / \mathrm{W}$ 型濃厚エマル ション系内部に打ける非定常熱移動現象の測定, 家政誌, 58, 187-195 (2007).

14）水 珠子, 長尾慶子, $\mathrm{O} / \mathrm{W}$ 型および $\mathrm{W} / \mathrm{O}$ 型エマルション 加熱に打ける内部熱移動の測定, 食科工, 55, 215-223 (2008).

15）水 珠子, 長尾慶子, $\mathrm{O} / \mathrm{W}$ 型食用エマルション内部の熱移 動に及ぼす分散油滴径の影響, 日調科誌, 41, 227-223 (2008).

16) Mizu, T. and Nagao K., Effect of Baking Powder in Wheat Flour Dough on Its Thermal Conduction during Heating, Food Sci. Technol. Res., 15, 217-224 (2009).

17）松本孝芳, 分散系のレオロジー, (高分子刊行会, 京都), pp. 13-59 (1997).

18) Nagao, K. and Matsumoto, S., Retardation Phenomenon Applied to the Thermal Conduction in Foodstuffs during a Variety of Heating Procedures, Nihon Reoroji Gakkaishi (J. Soc. Rheology, Jpn.), 33, 93-100 (2005).

19）長島 昭, 移動速度論, (コロナ社, 東京), pp. 9-15 (2002).

20）甲藤好郎, 熱伝導論, (共立出版, 東京), pp. 13-16 (1964).

(平成 21 年 4 月 13 日受付，平成 21 年 10 月 15 日受理) 